May 2002 • NREL/CP-520-32200

\title{
GaNPAs Solar Cells Lattice-Matched to GaP
}

\section{Preprint}

\author{
J.F. Geisz, D.J. Friedman, and S. Kurtz
}

To be presented at the $29^{\text {th }}$ IEEE PV Specialists Conference

New Orleans, Louisiana

May 20-24, 2002

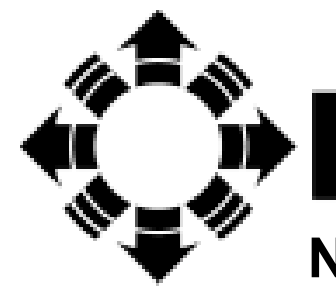

National Renewable Energy Laboratory

1617 Cole Boulevard

Golden, Colorado 80401-3393

NREL is a U.S. Department of Energy Laboratory

Operated by Midwest Research Institute • Battelle • Bechtel

Contract No. DE-AC36-99-G010337 


\section{NOTICE}

The submitted manuscript has been offered by an employee of the Midwest Research Institute (MRI), a contractor of the US Government under Contract No. DE-AC36-99G010337. Accordingly, the US Government and MRI retain a nonexclusive royalty-free license to publish or reproduce the published form of this contribution, or allow others to do so, for US Government purposes.

This report was prepared as an account of work sponsored by an agency of the United States government. Neither the United States government nor any agency thereof, nor any of their employees, makes any warranty, express or implied, or assumes any legal liability or responsibility for the accuracy, completeness, or usefulness of any information, apparatus, product, or process disclosed, or represents that its use would not infringe privately owned rights. Reference herein to any specific commercial product, process, or service by trade name, trademark, manufacturer, or otherwise does not necessarily constitute or imply its endorsement, recommendation, or favoring by the United States government or any agency thereof. The views and opinions of authors expressed herein do not necessarily state or reflect those of the United States government or any agency thereof.

Available electronically at http://www.osti.gov/bridge

Available for a processing fee to U.S. Department of Energy and its contractors, in paper, from:

U.S. Department of Energy

Office of Scientific and Technical Information

P.O. Box 62

Oak Ridge, TN 37831-0062

phone: 865.576 .8401

fax: 865.576.5728

email: reports@adonis.osti.gov

Available for sale to the public, in paper, from:

U.S. Department of Commerce

National Technical Information Service

5285 Port Royal Road

Springfield, VA 22161

phone: 800.553 .6847

fax: 703.605.6900

email: orders@ntis.fedworld.gov

online ordering: http://www.ntis.gov/ordering.htm

Printed on paper containing at least $50 \%$ wastepaper, including $20 \%$ postconsumer waste 


\title{
GaNPAs SOLAR CELLS LATTICE-MATCHED TO GaP
}

\author{
J.F. Geisz, D.J. Friedman, and Sarah Kurtz \\ National Renewable Energy Laboratory, Golden, CO 80401
}

\begin{abstract}
III-V semiconductors grown on silicon substrates are very attractive for lower-cost, high-efficiency multijunction solar cells, but lattice-mismatched alloys that result in high dislocation densities have been unable to achieve satisfactory performance. $\mathrm{GaN}_{\mathrm{x}} \mathrm{P}_{1-\mathrm{x}-\mathrm{y}} \mathrm{A} \mathrm{s}_{\mathrm{y}}$ is a direct-gap III-V alloy that can be grown lattice-matched to Si when $y=4.7 x-0.1$. We propose the use of latticematched GaNPAs on silicon for high-efficiency multijunction solar cells. We have grown $\mathrm{GaN}_{x} \mathrm{P}_{1-\mathrm{x}-\mathrm{y}} \mathrm{As}$, on $\mathrm{GaP}$ (with a similar lattice constant to silicon) by metalorganic chemical vapor phase epitaxy with direct bandgaps in the range of 1.5 to $2.0 \mathrm{eV}$. We demonstrate the performance of single-junction $\mathrm{GaN}_{\mathrm{x}} \mathrm{P}_{1-\mathrm{x}-\mathrm{y}} \mathrm{A} \mathrm{s}_{\mathrm{y}}$ solar cells grown on GaP substrates and discuss the prospects for the development of monolithic high-efficiency multijunction solar cells based on silicon substrates.
\end{abstract}

\section{INTRODUCTION}

State-of-the-art GalnP/GaAs/Ge and many proposed future generations of III-V high-efficiency solar cells are based on $\mathrm{GaAs}$ or Ge substrates [1]. In particular, much attention has been given to GalnNAs materials grown lattice-matched on $\mathrm{GaAs}$ over the past few years [2]. More recently, GaNP materials have been shown to become direct-gap with only a few \% N [3]. GaNPAs alloys have been grown lattice-matched to GaP [4] and Si [5] with band gaps that could be useful for solar cells. Growth on silicon substrates is very exciting because it would allow for significant cost savings of substrates and the potential for integration with existing Si technology. Lattice-mismatched III-V cells on Si substrates have been studied extensively, but the reduction of defect densities remains a significant challenge that typically requires complex graded buffer layers [6-8]. Nearly lattice-matched

$\mathrm{Al}_{0.01} \mathrm{Ga}_{0.99} \mathrm{~N}_{0.01} \mathrm{P}_{0.99}$ on Si solar cells has

\begin{tabular}{|c|}
\hline $1.7 \mathrm{eV}$ GaNPAs junction \\
\hline tunnel junction \\
\hline $\begin{array}{c}1.1 \mathrm{eV} \text { Silicon junction } \\
\text { (silicon substrate) }\end{array}$ \\
\hline
\end{tabular}

Fig. 1. Proposed latticematched GaNPAs on silicon tandem solar cell. been proposed [9], but this composition limits the range of band gaps available. We propose a structure based on lattice-matched $\mathrm{GaN}_{\mathrm{x}} \mathrm{P}_{1-\mathrm{x}-\mathrm{y}} \mathrm{As}$, , hereafter GaNPAs, alloys grown on silicon. The solar cell structure shown in Fig. 1 composed of a lattice-matched III-V cell grown on a Si cell could potentially rival the efficiencies of highefficiency cells on GaAs or $\mathrm{Ge}$, with significant cost savings and improvements in mechanical stability. Indeed, a two-junction cell composed of a 1.65-eV to 1.75eV GaNPAs junction on a 1.1-eV silicon junction has a nearly optimal set of band gaps for high efficiency solar cells, as shown in Fig. 2.

$\mathrm{GaP}$ is only $0.36 \%$ lattice-mismatched with silicon, and growth on GaP substrates avoids some of the diffi-

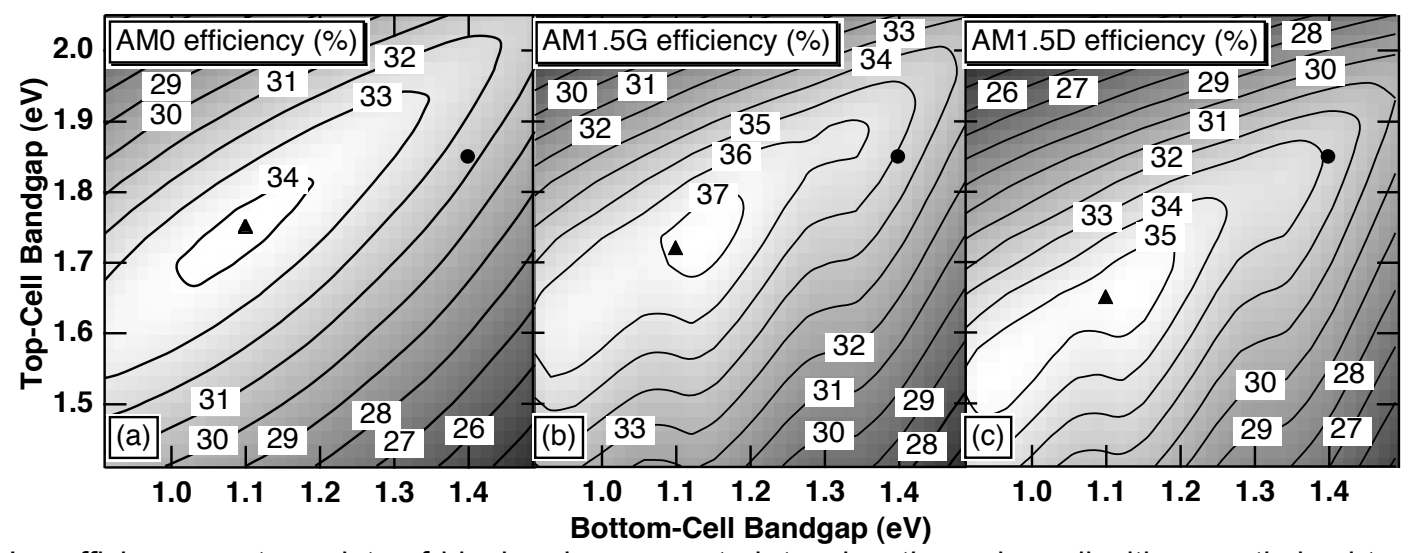

Fig. 2. Iso-efficiency contour plots of ideal series-connected, two-junction solar cell with an optimized top cell thickness [10], as a function of top-cell and bottom-cell direct band gap using standard spectra: (a) AM0 (space), (b) AM1.5 global (terrestrial), (c) AM1.5 direct (concentrator terrestrial). All efficiencies were calculated at $300 \mathrm{~K}$ and 1-sun conditions. The triangles show optimal GaNPAs/Si tandems and the circles show the standard GalnP/GaAs tandem cell. 
culties associated with growth on silicon. Therefore, as a first step, we study here GaNPAs solar cells grown on GaP substrates.

\section{MATERIAL PROPERTIES}

GaNPAs layers were grown by atmosphericpressure metal-organic vapor-phase epitaxy (MOVPE) on (001)-oriented, double-side-polished GaP wafers using trimethylgallium (TMG) or triethylgallium (TEG), unsymmetric-dimethylhydrazine $(\mathrm{DMH})$, phosphine $\left(\mathrm{PH}_{3}\right)$, and t-butylarsine as sources. Growth was performed at $600^{\circ}-700^{\circ} \mathrm{C}$, with nominal growth rates (GR) of 2-4 $\square \mathrm{m} / \mathrm{h}$, and $\mathrm{PH}_{3} / \mathrm{Ga}$ ratios of $6-52$. Incorporation efficiencies of the group $\mathrm{V}$ elements follow the trend of As $>\mathrm{P}>\mathrm{N}$ and are highly temperature dependent. While $\mathrm{N}$ incorporation drops off with increasing temperature, $P$ incorporation increases relative to As. Thus, achieving the intended compositions required a sensitive balance between group $\mathrm{V}$ source flows and temperature. By carefully adjusting the group $\mathrm{V}$ flows, alloys nearly lattice-matched to GaP were grown.

A series of nominally GaNPAs layers were grown directly on double-side-polished, undoped GaP substrates to determine the absorption coefficient $(\square)$. Simultaneous reflectance $(R)$ and transmittance $(T)$ measurements of the layer were used to determine $\square(\square)$ below the band gap energy of the GaP substrate, and spectral ellipsometry (SE) measurements were used above the band gap of the substrate. Fig. 3 shows the absorption for several different compositions of GaNPAs. The strong direct-like absorption in this spectral range indicates that these alloys may be quite useful as solar cell absorber layers. The absorption edge indicated band gaps in the range of 1.5 to $2.0 \mathrm{eV}$ for different compositions lattice-matched to $\mathrm{GaP}$.

Double-crystal x-ray diffraction (DCXRD) was performed in the (004) reflection and, in some cases, (115)

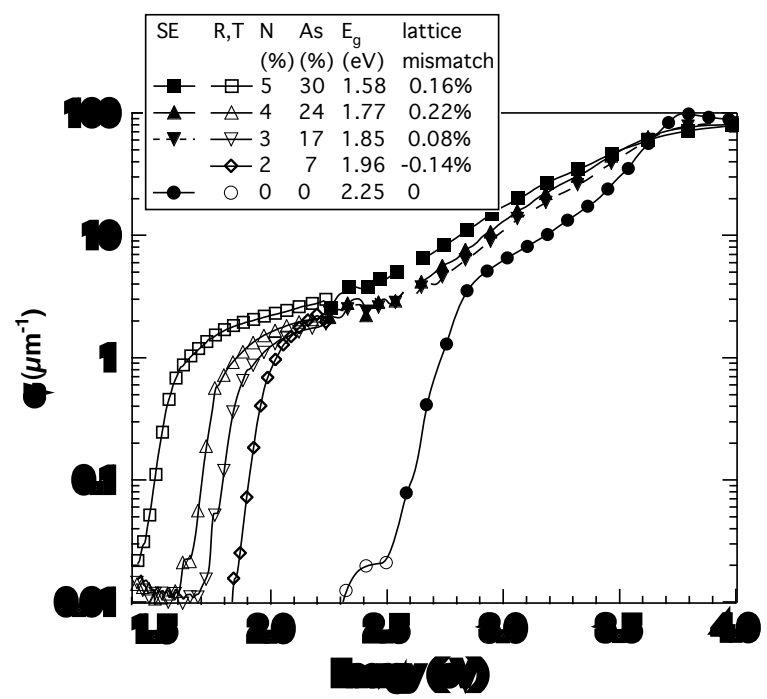

Fig. 3. Absorption coefficient of $\mathrm{GaN}_{\mathrm{x}} \mathrm{P}_{1-\mathrm{x}-\mathrm{y}} \mathrm{A} \mathrm{s}_{\mathrm{y}}$ layers grown on GaP substrates. The GaP substrate is shown as circles.

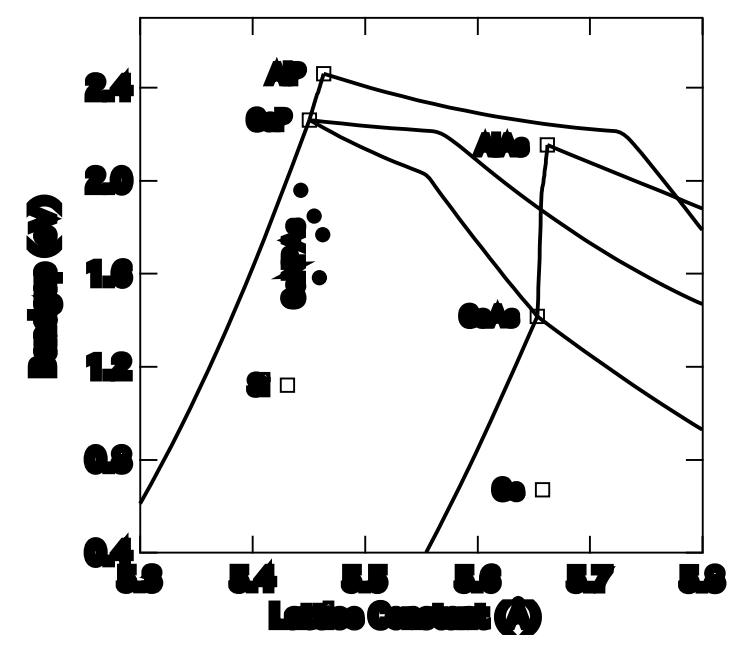

Fig. 4. Band gap vs. lattice constant of III-V semiconductors including data for GaNPAs alloys from Fig. 3.

reflections. Nitrogen composition in GaNP was estimated using Vegard's law. Although the nitrogen and arsenic composition in GaNPAs could not be unambiguously determined from these measurements, the peak splitting, 70 , was used to determine the average lattice parameter of the material. The compositions were then estimated based on the measured lattice parameter and the pseudo-binary bowing parameters of GaNP $(\sim 15 \mathrm{eV})$, GaNAs ( 15 eV), and GaPAs [11]. Fig. 4 shows how closely the GaNPAs layers were lattice-matched to GaP and Si.

\section{SOLAR CELLS}

The simple single heterojunction cell design shown in Fig. 5 was used to study these GaNPAs cells. The cells consisted of a Zn-doped GaP back surface field, an undoped GaNPAs base, a Se- or Si-doped GaP emitter, and a Se-doped GaAs contact layer. The cells were grown on Zn-doped (001) GaP substrates. The active GaNPAs base was grown at $700^{\circ} \mathrm{C}$. Au/Zn/Au back-side contacts and $\mathrm{Au} / \mathrm{Sn} / \mathrm{Au}$ front-side contacts were deposited and annealed at $450^{\circ} \mathrm{C}$. Devices were isolated with a $\mathrm{KMnO}_{4} / \mathrm{HF} / \mathrm{H}_{2} \mathrm{O}$ mesa etch. The GaAs contact layer was selectively etched with a solution of $\mathrm{NH}_{4} \mathrm{OH} / \mathrm{H}_{2} \mathrm{O}_{2} / \mathrm{H}_{2} \mathrm{O}$.

The carrier concentration in the nominally undoped GaNPAs base and similar layers was measured by capacitance-voltage (CV) measurements. The layers were consistently found to be p-type (on the order of $1 \times 10^{16} \mathrm{~cm}^{-3}$ )

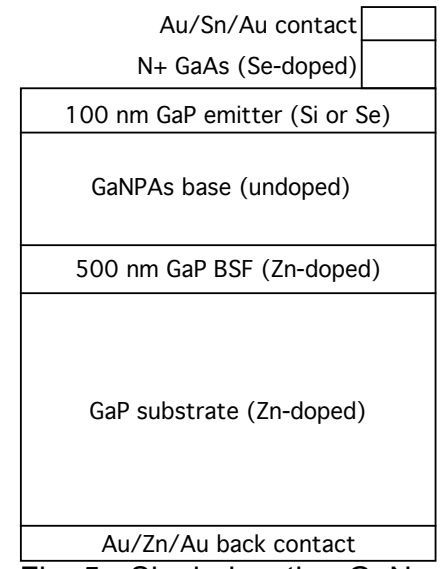

Fig. 5. Single-junction GaNPAs cell structure. 

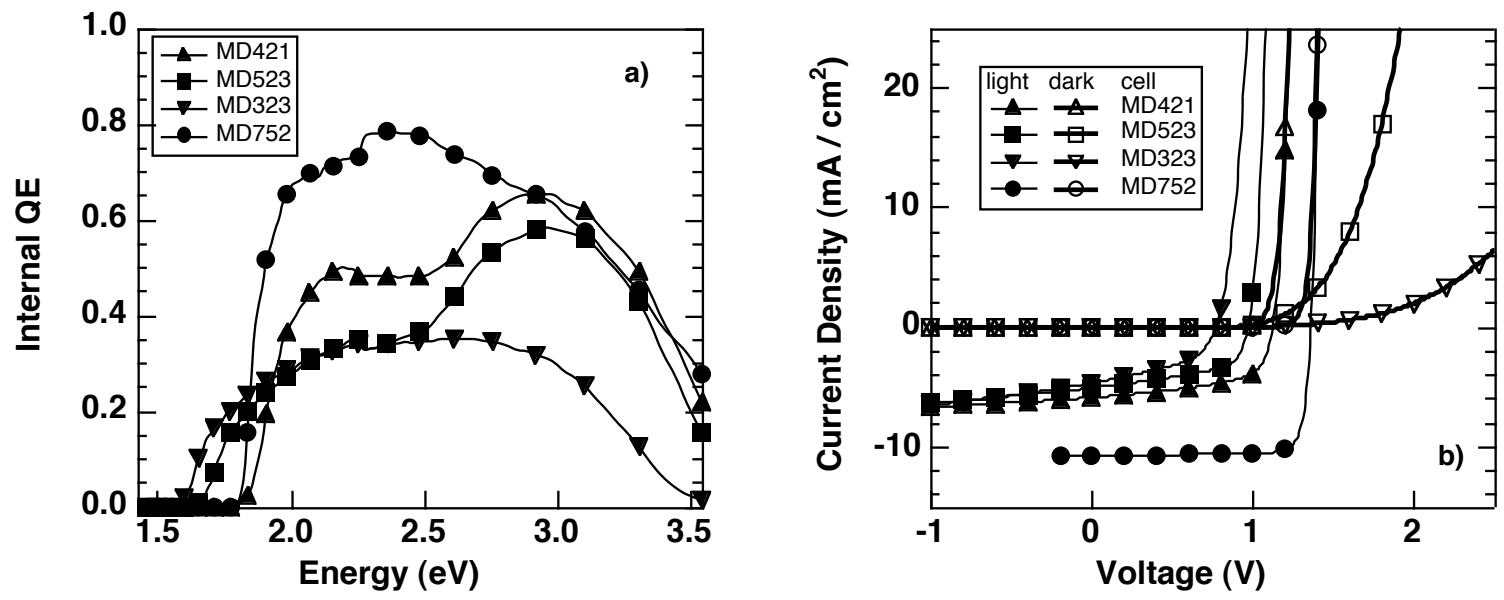

Fig. 6. (a) Internal quantum efficiency of three solar cells with different compositions of GaNPAs nearly latticematched to GaP and a GalnP cell for comparison, and (b) current-voltage curves of the same solar cells under AM1.5G conditions. A summary of these cells is listed in Table 1.

under normal measurement conditions, but were depleted when measured in the dark. Estimates of the base thickness determined from this depleted CV measurement are given in Table 1.

The external quantum efficiency (QE) and reflectance of the cells were measured to calculate the internal QE. The internal QE is shown in Fig. 6a for three solar cells with different compositions of GaNPAs along with a standard GalnP solar cell (MD752) with a similar band gap for comparison. The integrated current was calculated from the AM1.5 global spectrum and used to set the light level on an XT-10 solar simulator. The current-voltage (IV) curves were measured both in the light and dark. The IV curves corresponding to the cells from Fig. $6 a$ are shown in Fig. 6b. A summary of the devices is given in Table 1.

The increased QE for cells MD421 and MD523 above $2.5 \mathrm{eV}$ (the direct gap of $\mathrm{GaP}$ ) probably comes from collection in the GaP emitter layer. The collection of blue light in these cells compares favorably with the AllnP-passivated GalnP cell, MD752, in spite of the lack of a passivating window layer in our design. An AIGaP window layer may further improve the blue response of these cells. The GaP emitter in MD323 was grown at $650^{\circ}$ rather than $700^{\circ} \mathrm{C}$ using Se-doping rather than Sidoping. The lack of an increased $\mathrm{QE}$ above $2.5 \mathrm{eV}$ indicates a lower quality of the GaP emitter in MD323.

The QE below $2.5 \mathrm{eV}$ comes entirely from collection in the GaNPAs base layer, as this is the only layer of the structure with significant absorption in this region. A

Table 1. Solar Cell Device Parameters (AM1.5G).

\begin{tabular}{|l|l|c|c|c|c|c|c|c|c|}
\hline sample & $\begin{array}{c}\text { base } \\
\text { material }\end{array}$ & $\begin{array}{c}\mathrm{E}_{\mathrm{g}} \\
(\mathrm{eV})\end{array}$ & $\begin{array}{c}\mathrm{J}_{\mathrm{sc}} \\
\left(\mathrm{mA} / \mathrm{cm}^{2}\right)\end{array}$ & $\begin{array}{c}\mathrm{V}_{\mathrm{oc}} \\
(\mathrm{V})\end{array}$ & $\begin{array}{c}\mathrm{FF} \\
(\%)\end{array}$ & $\begin{array}{c}\text { Ga } \\
\text { source }\end{array}$ & $\begin{array}{c}\text { Emitter } \\
\text { dopant }\end{array}$ & $\begin{array}{c}\mathrm{t}_{\text {Base }} \\
(\square \mathrm{m})\end{array}$ & $\begin{array}{c}\mathrm{GR} \\
(\square \mathrm{m} / \mathrm{h})\end{array}$ \\
\hline MD421 & $\mathrm{GaN}_{0.03} \mathrm{P}_{0.83} \mathrm{As}_{0.14}$ & 1.88 & 5.8 & 1.12 & 60 & $\mathrm{TEG}$ & $\mathrm{Si}$ & 0.64 & 2.5 \\
MD523 & $\mathrm{GaN}_{0.05} \mathrm{P}_{0.69} \mathrm{As} \mathrm{s}_{0.26}$ & 1.69 & 5.0 & 0.97 & 56 & $\mathrm{TEG}$ & $\mathrm{Si}$ & $\sim 1$ & 4.0 \\
MD323 & $\mathrm{GaN}_{0.05} \mathrm{P}_{0.68} \mathrm{As}$ & & & \\
MD727 & 1.62 & 4.6 & 0.77 & 46 & TMG & $\mathrm{Se}$ & 0.89 & 4.0 \\
$\mathrm{Ga}_{0.5} \mathrm{I}_{0.5} \mathrm{P}$ & 1.83 & 10.7 & 1.36 & 85 & $\mathrm{TEG}$ & $\mathrm{Se}$ & 0.5 & 4.4 \\
\hline
\end{tabular}

$0.64-\square \mathrm{m}$-thick base layer should absorb more than $60 \%$ of the light above the band gap of the layer based on the absorption coefficients presented in Fig. 3. The thicker layers should absorb more than $80 \%$. The relatively low quantum efficiencies in this region indicate a problem with the material quality (diffusion length) of the GaNAsP. This problem is similar to the short diffusion lengths observed in GalnNAs [2]. The cells with lower nitrogen content $(\sim 3 \%)$ and higher band gap in general seem to be able to achieve slightly higher QE than the cells with more nitrogen $(\sim 5 \%)$, as represented by the data in Fig. 6a.

The performance of these GaNPAs cells is less than ideal. The short-circuit current $\left(\mathrm{J}_{\mathrm{sc}}\right)$, open-circuit voltage $\left(\mathrm{V}_{\mathrm{oc}}\right)$, and fill factor $(\mathrm{FF})$ of the GaNPAs cells are all significantly less than the values of the GalnP cell (MD752) with a comparable band gap. The shunt in the light IV curves, but not the dark IV curves, indicates field-aided collection.

An additional problem can be observed in the dark IV of the cells. A shift in the dark IV relative to the light IV suggests important differences in the material properties in the light and dark. Again, this IV shift is more pronounced in cells with higher nitrogen content and lower band gap. To better understand this difference in the light and dark, CV measurements were performed under different levels of light: dark, ambient, and under an intense desk lamp. The capacitance was measured from 0 to $2 \mathrm{~V}$ reverse bias, and the resulting carrier concentration versus depletion width data is plotted in Fig. 7. The free carrier concentration in the GaNPAs base of these two cells changed significantly under different light bias conditions. In the dark, both cells appear to be completely depleted, 
but as the light bias was increased, the free hole concentration increased. The change in hole concentration was more dramatic in MD323 than MD421. The shifted dark-IV curves are probably the result of the resistive nature of the depleted GaNPAs base. Such photoconductive behavior is reminiscent of oxygen-contaminated AllnP and amorphous silicon.

As a result of the light bias-dependent carrier concentration, the QE is also dependent on light bias. The $Q E$ increases with reduced light level because of the increased depletion width. The QE should therefore be measured under a one-sun light bias. Since we measured the $\mathrm{QE}$ under less than a one-sun light bias, our values of $J_{s c}$ are overestimated.

The light-dependent carrier concentration of the GaNPAs material suggests the presence of a deep trap state, which can be filled by photogenerated carriers. Such a deep trap may also explain the low quantum efficiencies of the devices.

Future work will focus on improving and understanding the electrical properties of GaNPAs materials and the growth of lattice-matched GaNPAs on silicon substrates. The growth of lattice-matched GaNPAs on silicon is challenging due to the polarity and thermal expansion mismatch between III-V and silicon. Fortunately, these problems seem to have been solved to some extent [5].

\section{CONCLUSION}

Lattice-matched GaNPAs solar cells on GaP substrates have been demonstrated with absorption characteristics appropriate for the top cell of an optimal latticematched III-V on silicon tandem solar cell. The performance of these cells was less than ideal, suggesting problems with the electrical quality of this novel material. Photoconductive behavior of this material has been identified as the cause of a shift in the dark-IV curve relative to the light-IV curve. Further study of the growth and properties of GaNPAs may allow for improvements that result in a lower-cost, high-efficiency tandem solar cell device.

\section{ACKNOWLEDGEMENTS}

We thank C. Kramer, M. Young, and A. Duda for assistance in the preparation and measurement of these devices. This work was funded by the U.S. Department of Energy, under Contract No. DE-AC36-99GO10337.

\section{REFERENCES}

[1] S.R. Kurtz, D. Myers, and J.M. Olson, "Projected Performance of Three- and Four-Junction Devices using GaAs and GalnP", 26th IEEE Photovoltaic Specialists Conference, 1997, pp. 875-878.

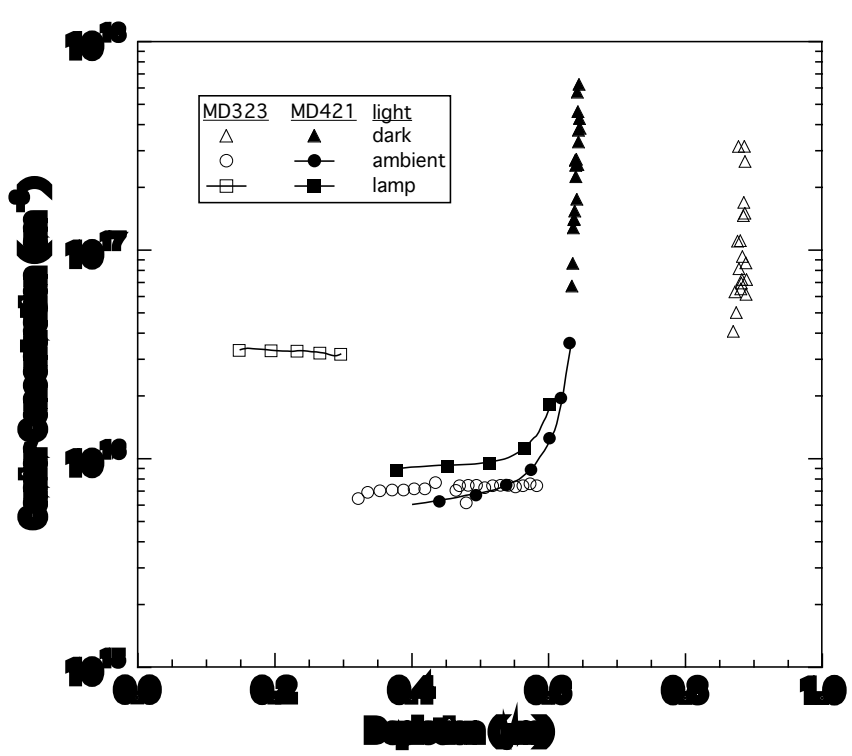

Fig. 7. Carrier concentration vs. depletion depth of two GaNPAs cells as measured by CV under different light conditions.

[2] J.F. Geisz and D.J. Friedman, "III-N-V semiconductors for solar photovoltaic applications", Semiconductor Science and Technology, 2002 in press.

[3] H.P. Xin, C.W. Tu, Y. Zhang, and A. Mascarenhas, "Effects of nitrogen on the band structure of $\mathrm{GaN}_{\mathrm{x}} \mathrm{P}_{1-\mathrm{x}}$ alloys", Appl. Phys. Lett. 76, 2000, pp. 1267-1269.

[4] G. Biwa, H. Yaguchi, K. Onabe, and Y. Shiraki, "Metalorganic vapor-phase epitaxy of $\mathrm{GaP}_{1-\mathrm{x}-\mathrm{y}} \mathrm{As}_{\mathrm{y}} \mathrm{N}_{\mathrm{x}}$ quaternary alloys on GaP", J. Cryst. Growth 190, 1998, pp. 485-489.

[5] Y. Fujimoto et al., "Dislocation-free $\mathrm{GaAs}_{y} \mathrm{P}_{1-\mathrm{x}-\mathrm{y}} \mathrm{N}_{\mathrm{x}}$ $/ \mathrm{GaP}_{0.98} \mathrm{~N}_{0.02}$ quantum-well structure lattice-matched to a Si substrate", Appl. Phys. Lett. 79, 2001, pp. 1306-1308.

[6] J.M. Olson, M.M. Al-Jassim, A. Kibbler, and K.M. Jones, "MOCVD growth and characterization of GaP on Si", J. Cryst. Growth 77, 1986, pp. 515.

[7] T. Soga et al., "High efficiency AIGaAs/Si monolithic tandem solar cell grown by metalorganic chemical vapor deposition", J. Appl. Phys. 78, 1995, pp. 4196-4199.

[8] J.A. Carlin et al., "High Efficiency GaAs-on-Si Solar Cells with High Voc Using Graded GeSi Buffers", 28th IEEE Photovoltaic Specialists Conference, 2000, pp. 1006.

[9] Y.G. Hong and C.W. Tu, "Ga(In)NAs and (Al)GaNP: Potential materials for photovoltaics", 199th Meeting of the Electrochemical Society, 2001, pp. 415-422.

[10] S.R. Kurtz, P. Faine, and J.M. Olson, "Modeling of two-junction, series-connected tandem solar cells using top-cell thickness as an adjustable parameter", J. Appl. Phys. 68, 1990, pp. 1890.

[11] S. Adachi, Physical Properties of III-V Semiconductior Compounds--InP, InAs, GaAs, GaP, InGaAs, and InGaAsP (John Wiley \& Son, New Youk, 1992). 


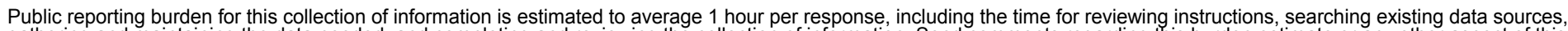

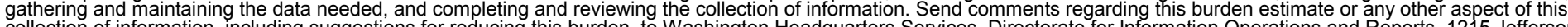
Davis Highway, Suite 1204, Arlington, VA 22202-4302, and to the Office of Management and Budget, Paperwork Reduction Project (0704-0188), Washington, DC 20503.
1. AGENCY USE ONLY (Leave blank)
2. REPORT DATE
May 2002
3. REPORT TYPE AND DATES COVERED
$29^{\text {th }}$ IEEE PVSC-Conference Paper

May 20-24 2002

4. TITLE AND SUBTITLE

GaNPAs Solar Cells Lattice-Matched To GaP: Preprint

6. $\operatorname{AUTHOR}(\mathrm{S})$

J.F. Geisz, D.J. Friedman, and S. Kurtz

7. PERFORMING ORGANIZATION NAME(S) AND ADDRESS(ES)

National Renewable Energy Laboratory

1617 Cole Blvd.

Golden, CO 80401-3393

9. SPONSORING/MONITORING AGENCY NAME(S) AND ADDRESS(ES)

National Renewable Energy Laboratory

1617 Cole Blvd.

Golden, CO 80401-3393
5. FUNDING NUMBERS PVP24401

8. PERFORMING ORGANIZATION REPORT NUMBER

10. SPONSORING/MONITORING AGENCY REPORT NUMBER

NREL/CP-520-32200

11. SUPPLEMENTARY NOTES

12a. DISTRIBUTION/AVAILABILITY STATEMENT

National Technical Information Service

U.S. Department of Commerce

5285 Port Royal Road

Springfield, VA 22161

12b. DISTRIBUTION CODE

13. ABSTRACT (Maximum 200 words): This conference paper describes the III-V semiconductors grown on silicon substrates are very attractive for lower-cost, high-efficiency multijunction solar cells, but lattice-mismatched alloys that result in high dislocation densities have been unable to achieve satisfactory performance. $\mathrm{GaN}_{\mathrm{x}} \mathrm{P}_{1-\mathrm{x}-\mathrm{y}} \mathrm{As}$, is a direct-gap III-V alloy that can be grown lattice-matched to Si when $y=4.7 x-0.1$. We propose the use of lattice-matched GaNPAs on silicon for high-efficiency multijunction solar cells. We have grown $\mathrm{GaN}_{\mathrm{x}} \mathrm{P}_{1-\mathrm{x}-\mathrm{y}} \mathrm{As} \mathrm{s}_{\mathrm{y}}$ on $\mathrm{GaP}$ (with a similar lattice constant to silicon) by metal-organic chemical vapor phase epitaxy with direct band-gaps in the range of 1.5 to $2.0 \mathrm{eV}$. We demonstrate the performance of singlejunction $\mathrm{GaN}_{\mathrm{x}} \mathrm{P}_{1-\mathrm{x}-\mathrm{y}} \mathrm{As}_{\mathrm{y}}$ solar cells grown on $\mathrm{GaP}$ substrates and discuss the prospects for the development of monolithic highefficiency multijunction solar cells based on silicon substrates.

14. SUBJECT TERMS: PV: III-V semiconductors; multijunction solar cells; lattice-match; metalorganic chemical vapor phase; spectral ellipsometry (SE); front-side contacts; capacitance voltage (CV); quantum efficiency (QE); short-circuit current; amorphous silicon;

17. SECURITY CLASSIFICATION OF REPORT Unclassified
18. SECURITY CLASSIFICATION OF THIS PAGE Unclassified
19. SECURITY CLASSIFICATION OF ABSTRACT

Unclassified
15. NUMBER OF PAGES

16. PRICE CODE

20. LIMITATION OF ABSTRACT

UL 